\title{
Childhood Disruptive Behaviour and School Performance across Comprehensive School: A Prospective Cohort Study
}

\author{
Saija Alatupa ${ }^{1}$, Laura Pulkki-Råback ${ }^{1,2}$, Mirka Hintsanen ${ }^{1}$, Sari Mullola ${ }^{3}$, \\ Jari Lipsanen $^{1}$, Liisa Keltikangas-Järvinen ${ }^{1 *}$ \\ ${ }^{1}$ IBS, Unit of Personality, Work and Health Psychology, University of Helsinki, Helsinki, Finland; \\ ${ }^{2}$ Finnish Institute of Occupational Health, Topeliuksenkatu 41 A, Helsinki, Finland; \\ ${ }^{3}$ Centre for Research on Teaching, Department of Teacher Education, \\ University of Helsinki, Helsinki, Finland. \\ Email: *Liisa.Keltikangas-Jarvinen@helsinki.fi \\ Received June 17 $7^{\text {th }}, 2011$; revised July 19 ${ }^{\text {th }}, 2011$; accepted August 22 $2^{\text {nd }}, 2011$.
}

\begin{abstract}
In the present study we examined 1) whether childhood disruptive behaviour, in terms of aggressiveness, hyperactivity and social adjustment, predicts school performance since toddler age or whether becomes it relevant first since middle or late childhood, 2) whether gender differences within the associations between school performance and disruptive behaviour exist, and 3) whether there are trait specific effects in these associations, i.e. whether hyperactivity is more relevant determinant for later school success than aggression and social adjustment. The subjects were derived from a representative, population based cohort study where 3600 subjects we followed for 27 years since their childhood. Our sample consisted of 973 participants (516 girls) who were 3, 6 and 9 years of age at baseline and were followed over their whole compulsory education, i.e. $3^{\text {rd }}, 6^{\text {th }}$, and $9^{\text {th }}$ grades. The most prominent finding was a gender specific association between disruptive behaviour and school performance: hyperactivity predicted later school performance among girls whereas aggression predicted school performance among boys. The association between social adjustment and school performance was less clear. Disruptive behaviour at toddler age (at the age of 3) was not predictable for later school performance but it started to predict school performance at later age, i.e. when it was assessed at the ages of 6 and 9 , and the associations were true throughout the whole 9-year comprehensive school. Our findings suggest that early childhood disruptive behaviour has long-lasting effects. Thus, its intervention before the school entry would be of high importance.
\end{abstract}

Keywords: Aggression, Disruptive Behaviour, Gender, Hyperactivity, Prospective Study, School Performance, Social Adjustment, Socioeconomic Position (SEP)

\section{Introduction}

Disruptive behaviour is a composite of co-occuring negativistic externalizing behaviours that appear in childhood, and are likely to persist over time (Hinshaw, 1992b). The Diagnostic and Statistical Manual of Mental Disorders (DSM-IV-TR) (American Psychiatric Association, 2007) divides disruptive behaviour into social and cognitive elements. The social component of disruptive behaviour incorporates aggressiveness, opposition, and antisociality, while the cognitive component comprises hyperactivity, inattention, and impulsivity (Vitaro, Brendgen, Larose, \& Tremblay, 2005). The elements of social and cognitive disruptiveness are conceptually distinctive even though certain overlap exists (Hinshaw, 1992a; Hinshaw, 1992b). Further, the cognitive elements of disruptive behaviour, i.e. hyperactivity, inattention, and impulsivity are close to temperamental characteristics of activity (referring to the vigor and tempo of motor activity), distractibility (referring to the ease to get distracted by environmental low-level stimuli), and impulsivity (referring to the tendency to act before thinking), respectively.

Childhood disruptive behaviour has been associated with poor educational (Asendorpf, Denissen, \& van Aken, 2008; Fergusson \& Horwood, 1995; Hinshaw, 1992a; Hinshaw, 1992b; Vitaro, Larocque, Janosz, \& Tremblay, 2001; Vitaro et al., 2005) and social outcomes (Fergusson \& John Horwood, 1995; Tremblay \& Masselink, 1992), although previous studies have been cross-sectional (Johnson, McGue, \& Iacono, 2005), or follow-ups of rather short endurance (Johnson et al., 2005; Richman, Stevenson, \& Graham, 1982; Rutter, 1974; Trzesniewski, Moffitt, Caspi, Taylor, \& Maughan, 2006), conducted in samples from geographically limited area (Asendorpf et al., 2008; Breslau et al., 2009; Rutter, 1974) and in selected populations (Frick et al., 1991; Richman et al., 1982). In addition, most of the studies have focused on the association between disruptive behaviour and reading ability (Berger, Yule, \& Rutter, 1975; Heiervang, Stevenson, Lund, \& Hugdahl, 2001; Hinshaw, 1992b; Johnson et al., 2005; Willcutt \& Pennington, 2000) or between disruptive behaviour and achievement in standardized tests (Fergusson, Horwood, \& Lynskey, 1993; Fergusson \& John Horwood, 1995; Frick et al., 1991). It has been suggested, however, that the link between disruptive behaviour and academic achievement is stronger when the measurement of achievement reflects actual performance, such as grades, in the classroom (Hawkins \& Lishner, 1987). School grades may be considered as a direct feedback of school performance as they reflect the teacher-student relationship quality, i.e. whether the disruptive behaviour is a cause of problems between teacher and pupil (Hinshaw, 1992b). Thus, the GPAs may be seen as an indicator of actual school performance, as they reflect the grades in several school subjects. Poor school performance is an important indicator of educational and social outcomes since it is known to predict low educational level and low work performance (Kuncel, Credé, \& Thomas, 2005), unemployment (Kokko, 
Bergman, \& Pulkkinen, 2003), detrimental health behaviour (Lynch, Kaplan, \& Salonen, 1997), and health, such as adulthood obesity (Alatupa et al., 2010).

Additional evidence on the risk-proneness of disruptive behaviour emerges from studies that have focused on the same phenomena, but used different terms, such as externalizing behaviour, undercontrolled behaviour, explosive temper tantrums, and lack of emotional control (referring to aggression, compliance, lability, anxiety, passivity, stability, constructiveness and activity) with analogous purpose. Children with explosive behavioral styles also tend to have erratic life course patterns characterized by downward occupational mobility, irregular work lives and poor choices regarding their social lives as adults (Caspi, Elder, \& Bem, 1987). Low self-control is associated with school social adjustment in adolescence and long-term unemployment in adulthood, partly via problem drinking and poor occupational alternatives (Kokko \& Pulkkinen, 2000; Kokko, Pulkkinen, \& Puustinen, 2000).

Altogether, disruptive behaviour seems to have an extensive influence on several educational and social outcomes. Early interference is highly important, as the long-term consequences of disruptive behaviour constitute high-priced major public health issues. For more efficient intervention, it is important to identify the age at which the influence of disruptive behaviour sets in, i.e. whether the preschool years or even the toddler age is determinant for later school outcomes.

The effect of disruptive behavior may also vary by gender. Prevalence of externalizing disorders is rather equivalent before school age (Boylan, Vaillancourt, Boyle, \& Szatmari, 2007; Loeber, Burke, Lahey, Winters, \& Zera, 2000), but after the age of six, the prevalence is reported to be 2 to 4 fold higher among boys (Boylan et al., 2007; Rucklidge, 2010).

With regard to gender differences, not much research has been conducted to examine the associations between disruptive behaviour and school performance in terms of the GPAs. However, there is some evidence on the association between antisocial behaviour and reading ability which has been shown to be stronger among boys (Reinke, Herman, Petras, \& Ialongo, 2008; Trzesniewski et al., 2006; Trzesniewski et al., 2006; E. G. Willcutt \& Pennington, 2000; Willcutt \& Pennington, 2000), whereas a further study found no difference between girls and boys (Stevenson, Richman, \& Graham, 1985).

To summarize, although the association of disruptive behavior with school performance has been studied extensively, there are limitations in previous research such as: 1) lack of studies that would have measured disruptive behaviour in childhood, that is, already before school entry, 2) lack of studies examining school performance systematically at several occasions throughout comprehensive school, 3) lack of understanding on age- or gender differences in the associations, and finally 4) lack of studies conducted in population-based samples that are representative of the entire age cohort. These limitations have been acknowledged in the literature (e.g., Greenfield Spira \& Fischel, 2005; Loe \& Feldman, 2007).

The purpose of this study was to examine the association of disruptive behavior with later school performance in a prospective dataset where disruptive behavior was measured prior to school entry. The specific goals were: 1) to identify the age at which disruptive behaviour predicts poor school performance, and 2) to examine possible gender differences in this association. We used a prospective dataset of a geographically representative sample of Finnish pupils whose school grades were assessed on three occasions covering the entire comprehensive school: at $3^{\text {rd }}$, $6^{\text {th }}$, and $9^{\text {th }}$ grades.
On the basis of the literature our hypotheses were: First, disruptive behaviour predicts school performance over the comprehensive school and this predictive association may be seen already in behaviors before school-age. It has been suggested that disruptive behaviour is a stronger predictor school performance among boys, and consequently our second hypothesis was that the association may be more manifest in boys than in girls. Third, we expected that hyperactivity is a stronger predictor of school performance in early school years whereas aggression becomes more relevant at later age.

The Finnish educational system consists of nine years of compulsory schooling between the age of 7 and 15 . Virtually all (99\%) of schools are public schools having parallel curriculums which enables contacting all pupils in a certain age cohort. From each age group approximately $97 \%$ graduate in regular classes (of which approximately $7 \%$ are under special, individual supervising, approximately $2 \%$ in special, "tailored" class, and less than $1 \%$ leaves without this education) from this state-owned school. After comprehensive school, almost all students continue either in Senior High Schools (approximately $64 \%$ ) or Vocational Institutions (approximately 30\%) and less than $5 \%$ drop out from this secondary education.

\section{Methods}

\section{Participants}

The participants were from a population based prospective Young Finns study which is a nationally representative, randomly selected sample of 3596 healthy children and adolescents from six age cohorts $(3,6,9,12,15$, and 18 years at the baseline). Based upon the location of the university cities with a medical school, Finland was divided into five areas (Helsinki, Kuopio, Oulu, Tampere and Turku). In each area, 360 urban boys and girls and 360 rural boys and girls were randomly selected on the basis of their personal Social Insurance Institution's population register, which covers the whole population of Finland. Complete details of the sample are given elsewhere (Raitakari et al., 2003). The study plan was approved by the local committees of all the participating universities, and the study protocol of each study phase corresponded to the proposal by the World Health Organization. All subjects gave their written consent and the study was conducted in accordance with the Helsinki declaration.

The current study comprises 3-, 6-, and 9-year-old age cohorts whose disruptive behaviour was measured at the baseline examination in 1980. Originally, there were 1806 participants $(\mathrm{n}=577,583$, and 646 participants in the respective 3,6 , and 9 -year old cohorts). Exclusion of participants based on missing data resulted in a final sample of 973 participants $(n=225,347$, and 401 participants in the 3-, 6-, and 9-year-old cohorts, respectively). No data was imputed. The original Young Finns Sample had an equal proportion of boys and girls, but attrition analyses showed that girls were slightly over-represented in our sample (3-year-old 40.4\% girls vs. 37.6\% boys, 6-year-old $63.7 \%$ girls vs. $55.0 \%$ boys, and 9-year-old $64.7 \%$ girls vs. $59.4 \%$ boys). Compared to drop-outs, those who had stayed had higher GPAs ( $p$-values ranging from $<.001$ to .002), were lower in aggression ( $p$-values ranging from .004 and .519), and in hyperactivity ( $p$-values ranging from .004 and .046) and higher in social adjustment ( $p$-values ranging from $<.001$ and .118) and they had mothers with higher education ( $p$-values ranging from $<.001$ to .007$)$, although the differences were 
rather small (mean differences between GPAs varying from 0.22 to 0.45 and mean differences in maternal years of education were 0.68 and 1.15).

\section{Childhood Disruptive Behaviour}

The dimensions of disruptive behaviour were assessed in 1980 by the mothers of the participants with a questionnaire derived from the Health Examination Survey (Wells, 1980). This questionnaire was originally designed to screen children with potential behavioural problems, and can be completed by non-professionals (by persons without a background in psychology). Table 1 presents the items of the three dimensions of disruptive behaviour, i.e. aggression, hyperactivity and social adjustment. These scales have been tested for construct validity (Katainen \& Raikkonen, 1999; Räikkönen, Katainen, Keskivaara, \& Kelikangas-Järvinen, 2000) and predictive validity (Pesonen, Räikkönen, Keskivaara, \& Keltikangas-Järvinen, 2003; Pulkki-Råback, Elovainio, Kivimäki, Raitakari, \& Keltikangas-Järvinen, 2005) in relation to similar constructs.

\section{School Performance}

School performance was assessed by grade point averages (GPA) which is a standard measure of school performance in Finland. Grade point averages (GPAs) were based on school reports in the $3^{\text {rd }}, 6^{\text {th }}$ and $9^{\text {th }}$ grades with the respective ages of the participants being 9,12 , and 15 years. The GPAs are the means of marks in all school subjects, and are assessed on a scale from 4 to $10(4=$ fail, $5-6=$ poor, $7-8=\operatorname{good}$ and $9-10$ $=$ excellent). GPAs were assessed twice a year and all pupils are evaluated on the same subjects (e.g. math, biology, history) using similar criteria in each school. The GPAs were reported by the participants' mothers at the age of 9 (GPA at $3^{\text {rd }}$ school grade), and self-reported by the participants at the ages of 12 ( $6^{\text {th }}$ grade $)$ and 15 ( $9^{\text {th }}$ grade $)$.

\section{Maternal Educational Level}

Based on a recent meta-analysis, the impact of parental SEP on students' school performance ranges between $r=.28$ and .30 (Sirin, 2005). In Finland, maternal educational level explains $38 \%$ of the variance of a student's performance while the respective figure in $32 \%$ for paternal education (Kuusela, 2003). To examine possible socioeconomic confounding, maternal education was used as a covariate in the analyses.

\section{Study Design}

Table 2 shows the study design and the number of participants at each study phase. With an exception of the oldest cohort (9-year-olds), disruptive behaviour was assessed before school beginning, i.e. at the ages of three and six. With an exception of the youngest cohort (three years), GPAs were measured at three occasions $\left(3^{\text {rd }}, 6^{\text {th }}\right.$, and $9^{\text {th }}$ grades $)$.

\section{Statistical Methods}

As one study focus was on gender differences, all analyses were performed separately for girls and boys. To examine the association of childhood disruptive behaviour (aggression, hyperactivity, and social adjustment) with GPAs in the $3^{\text {rd }}, 6^{\text {th }}$, and $9^{\text {th }}$ grades, we computed linear regressions with the GPAs as the continuous dependent variables. These analyses were conducted separately in each age cohort to examine age-related differences in the association between disruptive behaviour and school performance.

We additionally used the repeated measures ANOVA proce-

Table 1.

Items of the childhood disruptive behaviour of aggression, hyperactivity and social adjustment.

\begin{tabular}{|c|c|c|}
\hline & Disruptive Behaviour & Range of scale / Item value \\
\hline \multicolumn{3}{|c|}{ Aggression, 6 items (Range $1-5^{\mathrm{a}}$ ) } \\
\hline 1. & Child shows physical aggression towards other children & $1-5$ \\
\hline 2. & Other children's parents often complain about the child's behavior & $1-5$ \\
\hline 3. & The child often fights & $1-5$ \\
\hline 4. & The child often swears & $1-5$ \\
\hline 5. & Other children often tell tales about him/her & $1-5$ \\
\hline 6. & The child often comes home to tell he/she has hurt himself/herself & $1-5$ \\
\hline \multicolumn{3}{|c|}{ Hyperactivity, 1 item (Range 1-4) } \\
\hline & Child is always controlled & 1 \\
\hline & Child is overactive or restless only occasionally, for instance when tired & 2 \\
\hline & Child is continuously more active than the average child or youth & 3 \\
\hline & Child is always extremely active and energetic, even restless & 4 \\
\hline \multicolumn{3}{|c|}{ Social adjustment, 1 item (Range 1-3) } \\
\hline & Child is always very co-operative and responsive to others & 1 \\
\hline & Child has sometimes problems with peers, but is mostly co-operative & 2 \\
\hline & Child shows continuous problems with peers & 3 \\
\hline
\end{tabular}

${ }^{\mathrm{a}} 1=$ the statement doesn't fit the child, $5=$ the statement totally fits the child 
Table 2.

Study design. Participant's age (years) at the measurements of disruptive behaviour and grade point averages (GPAs).

\begin{tabular}{cccccc}
\hline & \multicolumn{4}{c}{ Grade point average measurements } \\
\cline { 2 - 6 } $\begin{array}{c}\text { Participants' age (years) at the } \\
\text { measurement of disruptive behaviour in 1980 }\end{array}$ & \multicolumn{4}{c}{ Baseline } & \multicolumn{3}{c}{ Follow-up } \\
\cline { 2 - 6 } & $\mathrm{n}$ & 1980 & 1983 & 1986 & 1989 \\
\hline 3 & 225 & & $9\left(3^{\text {rd }}\right)$ & $12\left(6^{\text {th }}\right)$ \\
6 & 347 & & $9\left(3^{\text {rd }}\right)$ & $12\left(6^{\text {th }}\right)$ & $15\left(9^{\text {th }}\right)$ \\
9 & 401 & $9\left(3^{\text {rd }}\right)$ & $12\left(6^{\text {th }}\right)$ & $15\left(9^{\text {th }}\right)$ & \\
\hline
\end{tabular}

\# $=$ The analyses were conducted separately for the 3,6 , and 9 years-olds.

dure to examine association of disruptive behaviour with GPAs over the three measurements, i.e. $3^{\text {rd }}, 6^{\text {th }}$, and $9^{\text {th }}$. For this, the GPA measurements were employed as continuous dependent variable and each disruptive behaviour trait was entered separately as independent binary variable. For this, each of the traits was divided into low and high through median split. The GPA means were then plotted over the three measurements by childhood aggression, hyperactivity, and social adjustment.

All of the aforementioned analyses were conducted in two steps: without-adjustments and with an adjustment for years of maternal education. We used the Bonferroni correction in order to control for Type I error rate (Abdi, 2007). The critical $\alpha$ level of .050 was divided by 3 , which was the number of analyses performed in examining the three measurements of disruptive behaviour. We then used the adjusted $\alpha$ level of $.016(.050 / 3$ $=.016)$ as the critical significance value. All analyses were performed using the SPSS software (version 15.0)

\section{Results} 3 .

The characteristics of the participants are presented in Table

Boys scored lower on social adjustment in each of the cohorts ( $p$ values varying from .003 to .017). Girls had consistently higher GPAs than boys ( $p$ values in each school grade $<.001$ ).

The results of disruptive behaviour predicting the GPAs are shown separately for girls (Table 4) and for boys (Table 5). While disruptive behaviour at the age of three had no association with GPAs, consistent associations were found between disruptive behaviour at ages 6 and 9 and subsequent GPAs. Among girls, high hyperactivity at the age of six years predicted poorer GPAs at $3^{\text {rd }}, 6^{\text {th }}$, and $9^{\text {th }}$ grade. Additionally, high aggression at the age of nine years was associated with poorer GPAs in $6^{\text {th }}$ grade whereas social adjustment, assessed at the age of nine, predicted poor GPAs at $9^{\text {th }}$ grade.

Table 5 shows that among boys, high aggression at the age of nine years predicted poorer GPAs in the $3^{\text {rd }}$ and $6^{\text {th }}$ grade. In addition, we found that social adjustment at the age of nine predicted poor performance at $3^{\text {rd }}$ and $9^{\text {th }}$ grades. In girls and boys, the associations were robust against adjustment for maternal education (see Table 5).

To sum up, different aspects of disruptive behaviour seemed to predict school grades in boys and in girls. Hyperactivity was the strongest predictor of poor outcomes for girls, while high aggression was a more important determinant of boys' performance.

For illustrative purposes, we plotted the GPA means over the three measurements by disruptive behaviour as a binary out- come variable separately for girls (Figure 1) and boys (Figure 2 ). Figure 1 demonstrates that boys with high aggression had lower GPAs over the whole comprehensive school, i.e. at $3^{\text {rd }}$, $6^{\text {th }}$, and $9^{\text {th }}$ grade (adjusted for age and maternal education). The pairwise comparisons showed that the difference between boys with high and low aggression was significant in $6^{\text {th }}$ grade $(p$ $=.014)$ and almost significant in $9^{\text {th }}$ grade $(p=.018)$.

Figure 2 shows that girls with high hyperactivity had lower GPAs throughout the three measurements. The pairwise comparisons demonstrate that the GPA differences among girls with high and low hyperactivity were significant in $6^{\text {th }}$ and $9^{\text {th }}$ grade ( $p$ values in $6^{\text {th }}$ and $9^{\text {th }}$ grade were .001 and .011 , respectively).

In regard to social adjustment, the pairwise comparisons showed that the GPA differences were significant among girls in $3^{\text {rd }}$ and $9^{\text {th }}$ grade ( $p$ values .010 and .003 , respectively), and among boys in $6^{\text {th }}$ grade $(p=.014)$.

\section{Discussion}

The current study examined in a population-based sample whether the early, middle and late childhood disruptive behaviour in terms of aggression, hyperactivity, or social adjustment, predicts the school performance over the whole comprehensive school education.

Probably the most important result was that no trait specific effect but a gender specific effect was found. That means that against our hypothesis hyperactivity and aggression were as important factors in predicting school performance but they played different roles in different gender groups. High hyperactivity predicted poor GPAs among girls whereas high aggression predicted poor GPAs among boys. The association between disruptive behaviour and school performance was evident throughout the whole school career, even though it was likely to decrease along with age maintaining, however, statistical significance. The impact of social adjustment on school performance, however, was less consistent.

We found that disruptive behaviour in middle and late childhood predicted later school performance, whereas no association was found when children's behaviour was measured at toddler age. It is known that in age of three years disruptive behaviour is at least to certain degree age-appropriate, and not relevant predictor for later academic success as shown in the current study. In accordance with previous research (Caspi \& Henry, 1995) we found that disruptive behaviour becomes relevant to school performance when it is measured more proximal to the school beginning. In regard to children's age by the measurement of disruptive behaviour, we further support earlier research (Hinshaw, 1992b) by showing that hyperactivity associates stronger with school performance in elementary 
Table 3 .

Participant characteristics. The descriptive analyses were conducted separately for girls and boys separately within the 3-, 6-, and 9 year-old cohorts.

\begin{tabular}{|c|c|c|c|c|c|c|c|}
\hline & \multicolumn{3}{|c|}{ Girls } & \multicolumn{3}{|c|}{ Boys } & \multirow{2}{*}{$\mathrm{p}$} \\
\hline & $\mathrm{n}$ & \multicolumn{2}{|c|}{$\mathrm{M} \pm \mathrm{SD}$} & $\mathrm{n}$ & \multicolumn{2}{|c|}{$\mathrm{M} \pm \mathrm{SD}$} & \\
\hline Aggression (range 1 - 5) & 114 & 1.06 & 0.10 & 111 & 1.09 & 0.14 & 0.203 \\
\hline Social adjustment (range $1-3$ ) & 114 & 1.36 & 0.63 & 111 & 1.58 & 0.72 & 0.017 \\
\hline \multicolumn{8}{|l|}{ School performance } \\
\hline GPA in $3^{\text {rd }}$ grade & 114 & 8.07 & 0.53 & 111 & 7.76 & 0.57 & $<0.001$ \\
\hline GPA in $6^{\text {th }}$ grade & 114 & 8.18 & 0.64 & 111 & 7.81 & 0.65 & $<0.001$ \\
\hline Maternal education (range 6-22 years) & 114 & 11.34 & 3.15 & 111 & 11.34 & 3.33 & 0.999 \\
\hline \multicolumn{8}{|l|}{ 6-Year-Old Cohort $(\mathrm{N}=347)$} \\
\hline Aggression (range 1 - 5) & 193 & 1.06 & 0.13 & 154 & 1.06 & 0.11 & 0.988 \\
\hline Hyperactivity (range $1-4$ ) & 193 & 2.05 & 0.61 & 154 & 2.12 & 0.58 & 0.232 \\
\hline Social adjustment (range $1-3$ ) & 193 & 1.47 & 0.68 & 154 & 1.71 & 0.84 & 0.003 \\
\hline \multicolumn{8}{|l|}{ School performance } \\
\hline GPA in $3^{\text {rd }}$ grade & 193 & 8.03 & 0.50 & 154 & 7.75 & 0.59 & $<0.001$ \\
\hline GPA in $6^{\text {th }}$ grade & 193 & 8.20 & 0.64 & 154 & 7.84 & 0.73 & $<0.001$ \\
\hline Maternal education (range 4 - 21 years) & 193 & 11.0 & 3.24 & 154 & 11.58 & 3.39 & 0.103 \\
\hline \multicolumn{8}{|l|}{ 9-Year-Old Cohort $(\mathrm{N}=401)$} \\
\hline Aggression (range 1 - 5) & 209 & 1.04 & 0.11 & 192 & 1.07 & 0.14 & 0.060 \\
\hline Hyperactivity (range 1 - 4) & 209 & 2.07 & 0.64 & 192 & 2.04 & 0.46 & 0.584 \\
\hline Social adjustment (range 1 - 3) & 209 & 1.54 & 0.72 & 192 & 1.57 & 0.74 & 0.711 \\
\hline \multicolumn{8}{|l|}{ School performance } \\
\hline GPA in $3^{\text {rd }}$ grade & 209 & 7.95 & 0.58 & 192 & 7.62 & 0.55 & $<0.001$ \\
\hline GPA in $6^{\text {th }}$ grade & 209 & 8.10 & 0.70 & 192 & 7.69 & 0.72 & $<0.001$ \\
\hline GPA in $9^{\text {th }}$ grade & 209 & 8.19 & 0.82 & 192 & 7.68 & 0.89 & $<0.001$ \\
\hline Maternal education (range 6 - 22 years) & 209 & 10.44 & 2.91 & 192 & 10.62 & 3.43 & 0.563 \\
\hline
\end{tabular}

$\mathrm{a}=$ School performance is measured as grade point average (GPA) ranging from 4 to 10 ; The ages of participants in $3^{\text {rd }}, 6^{\text {th }}$, and $9^{\text {th }}$ grade are 9,12 , and 15 , respectively.

grades whereas aggression associates with school performance first by adolescence.

The association between aggression and school performance was stronger among boys than girls although aggression was not more common among boys. This finding is in contradiction with previous research showing that boys in general are more likely to show higher levels of aggressive behaviour (Archer, 2004; Rhee \& Waldman, 2002). Previous research suggests a gender related difference in regard to the acceptance of aggres- sive behaviour. For instance, toddler and preschool-aged girls' aggressive behaviour is more likely to be ignored by the teachers and the peers whereas it is reinforced among boys (Fagot \& Hagan, 1985; Serbin, O'leary, Kent, \& Toniek, 1973). Consequently, even though girls and boys show similar levels of aggression, it may be ignored among girls but not among boys. Previous literature has shown that the association between disruptive behaviour and academic performance is stronger among boys (Williams \& McGee, 1994), among girls (Maughan, 
Table 4 .

Standardized beta coefficients of disruptive behaviour in 3 different age groups in predicting grade point averages (GPAs) in the $3^{\text {rd }}$, $6^{\text {th }}$, and $9^{\text {th }}$ grades for girls. The results are shown separately for 3-, 6-, and 9-year old cohorts.

\begin{tabular}{|c|c|c|c|c|c|c|c|c|c|c|c|c|}
\hline & \multicolumn{4}{|c|}{ GPA in $3^{\text {rd }}$ grade $\alpha$} & \multicolumn{4}{|c|}{ GPA in $6^{\text {th }}$ grade $\alpha$} & \multicolumn{4}{|c|}{ GPA in $9^{\text {th }}$ grade $\alpha$} \\
\hline & $\mathrm{n}$ & $\beta$ & $\begin{array}{l}\text { Adjusted } \mathrm{R}^{2} \text { of } \\
\text { the model }\end{array}$ & $\begin{array}{c}\mathrm{R}^{2} \\
\text { change }\end{array}$ & $\mathrm{n}$ & $\beta$ & $\begin{array}{l}\text { Adjusted } \mathrm{R}^{2} \\
\text { of the model }\end{array}$ & $\begin{array}{c}\mathrm{R}^{2} \\
\text { change }\end{array}$ & $\mathrm{n}$ & $\beta$ & $\begin{array}{l}\text { Adjusted } R^{2} \text { of } \\
\text { the model }\end{array}$ & $\begin{array}{c}\mathrm{R}^{2} \\
\text { change }\end{array}$ \\
\hline \multicolumn{13}{|c|}{ 3-Year-Old Cohort } \\
\hline Aggression & 114 & -.121 & .006 & .015 & 114 & .004 & -.009 & .000 & & & & \\
\hline$+\mathrm{SEP}^{\mathrm{a}}$ & 114 & -.075 & .097 & .006 & 114 & .073 & .207 & .005 & & & & \\
\hline Hyperactivity & 114 & .079 & -.003 & .006 & 114 & -.040 & -.007 & .002 & & & & \\
\hline$+\mathrm{SEP}^{\mathrm{a}}$ & 114 & .091 & .103 & .008 & 114 & -.023 & .202 & .001 & & & & \\
\hline Social adjustment & 114 & -.151 & .014 & .023 & 114 & -.074 & -.003 & .006 & & & & \\
\hline$+\mathrm{SEP}^{\mathrm{a}}$ & 114 & -.136 & .110 & .019 & 114 & -.053 & .204 & .003 & & & & \\
\hline \multicolumn{13}{|c|}{ 6-Year-Old Cohort } \\
\hline Aggression & 193 & -.111 & .007 & .012 & 193 & -.156 & .019 & .024 & 193 & -.127 & .011 & .016 \\
\hline$+\operatorname{SEP}^{\mathrm{a}}$ & 193 & -.105 & .022 & .011 & 193 & -.144 & .092 & .021 & 193 & -.117 & .065 & .014 \\
\hline Hyperactivity & 193 & $-.185^{*}$ & .029 & .034 & 193 & $-.189 *$ & .031 & .036 & 193 & $-.185^{*}$ & .029 & .034 \\
\hline$+\mathrm{SEP}^{\mathrm{a}}$ & 193 & $-.175^{*}$ & .042 & .031 & 193 & $-.170^{*}$ & .100 & .029 & 193 & $-.168^{*}$ & .079 & .028 \\
\hline Social adjustment & 193 & $-.203 *$ & .036 & .041 & 193 & -.134 & .013 & .018 & 193 & .134 & .013 & .018 \\
\hline$+\mathrm{SEP}^{\mathrm{a}}$ & 193 & $-.185^{*}$ & .045 & .034 & 193 & -.095 & .080 & .009 & 193 & -.100 & .061 & .010 \\
\hline \multicolumn{13}{|c|}{ 9-Year-Old Cohort } \\
\hline Aggression & 209 & -.085 & .002 & .007 & 209 & $-.179 *$ & .027 & .032 & 209 & -.122 & .010 & .015 \\
\hline$+\mathrm{SEP}^{\mathrm{a}}$ & 209 & -.069 & .026 & .005 & 209 & -.158 & .077 & .025 & 209 & -.098 & .071 & .010 \\
\hline Hyperactivity & 209 & -.024 & -.004 & .001 & 209 & -.132 & .013 & .017 & 209 & -.109 & .007 & .012 \\
\hline$+\mathrm{SEP}^{\mathrm{a}}$ & 209 & -.022 & .022 & .000 & 209 & -.130 & .069 & .017 & 209 & -.107 & .073 & .011 \\
\hline Social adjustment & 209 & -.085 & .002 & .007 & 209 & -.104 & .006 & .011 & 209 & $-.197 * *$ & .034 & .039 \\
\hline$+\mathrm{SEP}^{\mathrm{a}}$ & 209 & -.096 & .031 & .009 & 209 & -.119 & .066 & .014 & 209 & $-.213^{* *}$ & .107 & .045 \\
\hline
\end{tabular}

Note: The time of the measurement of disruptive behaviour within the cohorts is the same as the cohort age; ${ }^{*} p<.017,{ }^{* *} p<.001 ;{ }^{a}=$ Childhood socioeconomic position in terms of maternal years of education; $\alpha=$ The ages of participants in the $3^{\text {rd }}, 6^{\text {th }}$, and $9^{\text {th }}$ grades are 9,12 , and 15 , respectively.

Pickles, Hagell, Rutter, \& Yule, 1996) and to be similar among both gender groups (E. G. Willcutt, Pennington, \& DeFries, 2000). Here we found that the association between aggression and school performance was true only among boys suggesting a gender specific role of aggression in academic achievement.

A gender specific association between hyperactivity and school performance was found, too. Hyperactivity was associated with poor school performance only among girls even though there were no gender differences in the mean levels of hyperactivity at any of the cohorts. Consequently, hyperactivity seems to play a different role for girls and boys. This is in accordance with a previous study carried out in the present sample showing that childhood hyperactivity predicted adulthood atherosclerosis (indicated by ultrasound measurements of carotid intima-media thickness) over 21 years of follow-up in women but not in men (Keltikangas-Jarvinen, Pulkki-Raback,
Puttonen, Viikari, \& Raitakari, 2006). There is, however, also evidence of stronger association among boys (McGee, Prior, Williams, Smart, \& Sanson, 2002).

Social adjustment is known to correlate with evoking disliking from the teachers, and with poor social status among peers (Dougherty, 2006; Newcomb, Bukowski, \& Pattee, 1993). In girls and boys, there were moderate evidence for the association between social adjustment and school performance. Previous research has suggested that a role of social adjustment in child's social status and social popularity is far from clear. Actually, a direct association exists in kindergarten, only (Johnson, Ironsmith, Snow, \& Poteat, 2000). Our finding suggests that the association between social adjustment and school performance is not consistent, either.

The most prominent result of the present study was the gender related difference between the associations of disruptive be- 
Table 5 .

Standardized beta coefficients of disruptive Behaviour in 3 different age groups in predicting grade point averages (GPAs) in the $3^{\text {rd }}$, $6^{\text {th }}$, and $9^{\text {th }}$ grades for boys. The results are shown separately for 3-, 6-, and 9-year old cohorts.

\begin{tabular}{|c|c|c|c|c|c|c|c|c|c|c|c|c|}
\hline & \multicolumn{4}{|c|}{ GPA in $3^{\text {rd }}$ graded } & \multicolumn{4}{|c|}{ GPA in $6^{\text {th }}$ graded } & \multicolumn{4}{|c|}{ GPA in $9^{\text {th }}$ graded } \\
\hline & $\mathrm{n}$ & $\beta$ & $\begin{array}{l}\text { Adjusted } \mathrm{R}^{2} \\
\text { of the model }\end{array}$ & $\begin{array}{c}\mathrm{R}^{2} \\
\text { change }\end{array}$ & $\mathrm{n}$ & $\beta$ & $\begin{array}{l}\text { Adjusted } \mathrm{R}^{2} \\
\text { of the model }\end{array}$ & $\begin{array}{c}\mathrm{R}^{2} \\
\text { change }\end{array}$ & $\mathrm{n}$ & $\beta$ & $\begin{array}{l}\text { Adjusted } \mathrm{R}^{2} \\
\text { of the model }\end{array}$ & $\begin{array}{c}\mathrm{R}^{2} \\
\text { change }\end{array}$ \\
\hline \multicolumn{13}{|c|}{ 3-Year-Old Cohort } \\
\hline Aggression & 111 & .045 & -.007 & .002 & 111 & -.029 & -.008 & .000 & & & & \\
\hline$+\mathrm{SEP}^{\mathrm{a}}$ & 111 & -.013 & .100 & .000 & 111 & -.056 & .066 & .003 & & & & \\
\hline Hyperactivity & 111 & .122 & .006 & .006 & 111 & .126 & .007 & .016 & & & & \\
\hline$+\mathrm{SEP}^{\mathrm{a}}$ & 111 & .056 & .103 & .003 & 111 & .072 & .068 & .005 & & & & \\
\hline Social adjustment & 111 & -.046 & -.007 & .002 & 111 & -.116 & .005 & .014 & & & & \\
\hline \multicolumn{13}{|c|}{ 6-Year-Old Cohort } \\
\hline Aggression & 154 & .037 & -.005 & .001 & 154 & -.115 & .007 & .013 & 154 & -.168 & .022 & .028 \\
\hline$+\mathrm{SEP}^{\mathrm{a}}$ & 154 & .099 & .074 & .009 & 154 & -.038 & .131 & .001 & 154 & -.092 & .145 & .008 \\
\hline Hyperactivity & 154 & .015 & -.006 & .000 & 154 & -.105 & .005 & .011 & 154 & -.184 & .028 & .034 \\
\hline$+\mathrm{SEP}^{\mathrm{a}}$ & 154 & .041 & .066 & .002 & 154 & -.071 & .135 & .005 & 154 & -.149 & .159 & .022 \\
\hline Social adjustment & 154 & .000 & -.007 & .000 & 154 & -.116 & .007 & .014 & 154 & .115 & .007 & .013 \\
\hline$+\mathrm{SEP}^{\mathrm{a}}$ & 154 & -.062 & .068 & .004 & 154 & .037 & .131 & .001 & 154 & -.033 & .138 & .001 \\
\hline \multicolumn{13}{|c|}{ 9-Year-Old Cohort } \\
\hline$+\mathrm{SEP}^{\mathrm{a}}$ & 192 & $-.255^{* *}$ & .158 & .064 & 192 & -.164 & .111 & .026 & 192 & -.140 & .119 & .019 \\
\hline Hyperactivity & 192 & -.076 & .001 & .006 & 192 & -.100 & .005 & .010 & 192 & -.118 & .009 & .014 \\
\hline$+\mathrm{SEP}^{\mathrm{a}}$ & 192 & -.035 & .094 & .001 & 192 & -.061 & .088 & .004 & 192 & -.076 & .106 & .006 \\
\hline Social adjustment & 192 & $-.214^{*}$ & .041 & .046 & 192 & -.155 & .019 & .024 & 192 & $-.180 *$ & .027 & .032 \\
\hline$+\mathrm{SEP}^{\mathrm{a}}$ & 192 & $-.199 *$ & .133 & .040 & 192 & -.141 & .105 & .020 & 192 & $-.165^{*}$ & .127 & .027 \\
\hline
\end{tabular}

Note: The time of the measurement of disruptive behaviour within the cohorts is the same as the cohort age; ${ }^{*} p<.017,{ }^{* *} p<.001 ;{ }^{\mathrm{a}}=\mathrm{Childhood}$ socioeconomic position in terms of maternal years of education; $q=$ The ages of participants in the $3^{\text {rd }}, 6^{\text {th }}$, and $9^{\text {th }}$ grades are 9,12 , and 15 , respectively.

haviour and school performance. Even though the mean levels of aggression and hyperactivity were not different between the gender groups, their impact on school performance was different. Recent findings in Finland have shown that the level of aggression in girls and boys has narrowed (Tilastokeskus, 2010), but it seems that gender related behavioural expectations still remain the same. This difference may result from cultural expectations, i.e. depending on the cultural gender role norms, some behavioural tendencies may be viewed as more or less appropriate or desirable in girls and boys (see meta-analysis and review by (Else-Quest, Hyde, Goldsmith, \& Hulle, 2006; McIntyre \& Edwards, 2009). For example, higher motor activity and aggressive tendencies may be better condoned among boys whereas silent and persistent working may be more expected from girls. However, these often tacit expectations regarding gender specific behaviours may have an important role on teacher's ratings. Indeed, teachers' ratings have been shown to be more gender typed than are parents' ratings, and it has been suggested that this may result from teachers' frequent observations of students' interactions among same gendered students, which in turn, have shown to magnify gender role differences (Else-Quest et al., 2006; Maccoby, 1990).

The strengths of the present study are as follows. We were able to use 1) a nationally representative, although somewhat selected, 2) prospective study over the whole comprehensive school (i.e. for over nine years). 3) We had the opportunity to examine disruptive behaviour before entering the school, i.e. at the time, when the school has not yet contributed on child's behaviour. Finally, 4) as the teachers receive the same education and all schools follow the same curriculum the Finnish school system can be seen as rather homogenous.

Certain limitations have to be taken into account when interpreting the present results. First limitation is linked with attrition. The persons lost to follow-up in each of the cohort were 

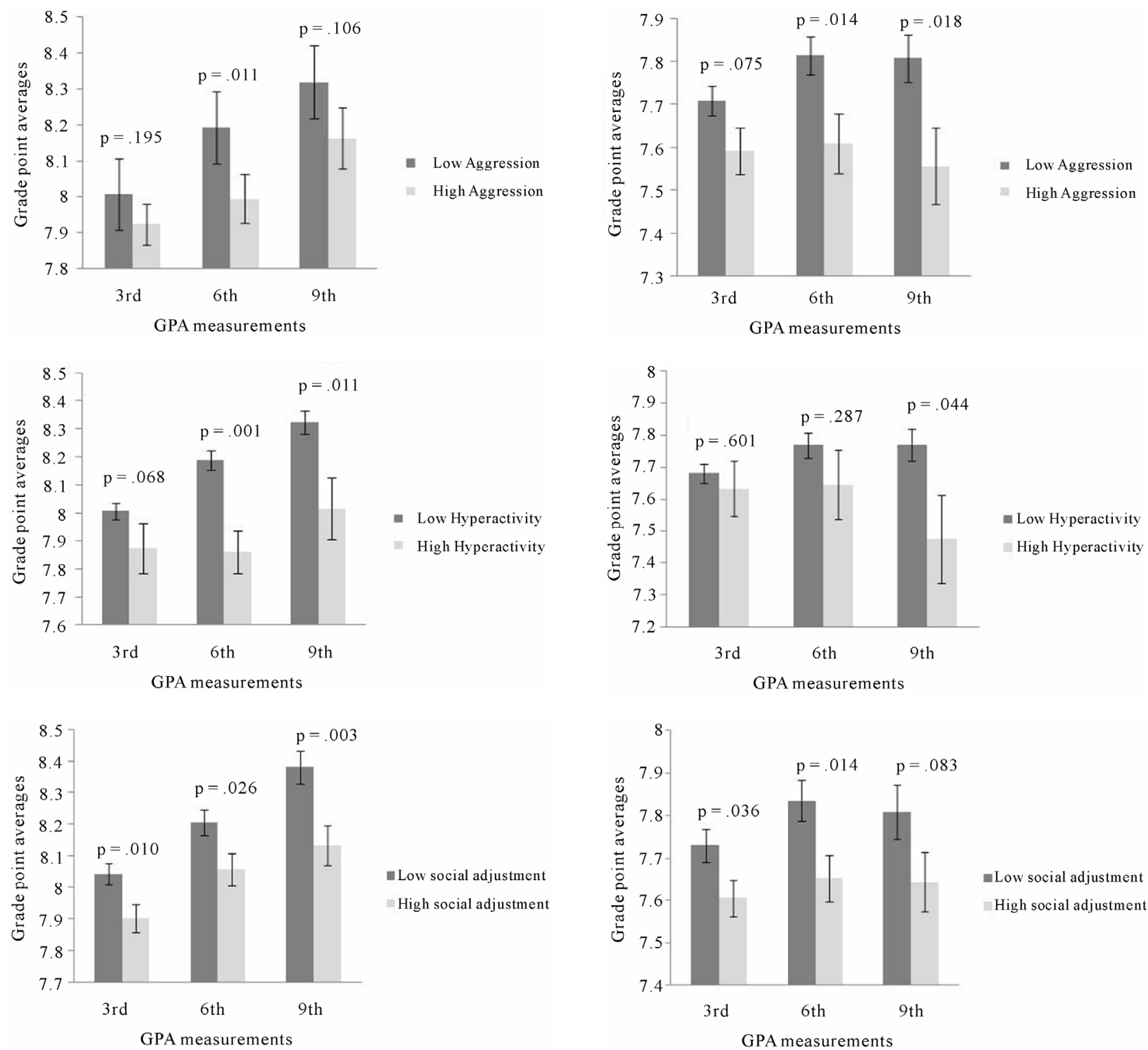

Figure 1.

The fully adjusted grade point averages (GPAs) over the three measurements $\left(3^{r d}, 6^{\text {th }}\right.$, and $9^{\text {th }}$ grade) among girls with low and high aggression, hyperactivity, and social adjustment, respectively.

more likely to be boys than girls, had lower GPAs throughout the measurements, and were from less educated families. This may at least partly be explained so that the most aggressive participants were excluded from the study.

Second limitation is related with the self reports of the school performance. Even though the self-reported GPAs may be biased through recall problems or social desirability, a recent meta-analysis suggest, however, that they reflect the actual performance reasonably well (Kuncel et al., 2005). In Finland, GPAs are often the most important source of student's academic achievement when applying for the secondary schooling and a certain level of achievement is mostly required to get a place to study. Previous research has also shown that GPAs at the end of comprehensive school predicts later academic, social and health outcomes (Alatupa et al., 2010; K. Kokko et al., 2003; Kuncel et al., 2005). Moreover, it has been shown that in Finland, school grades given by teachers are a more reliable

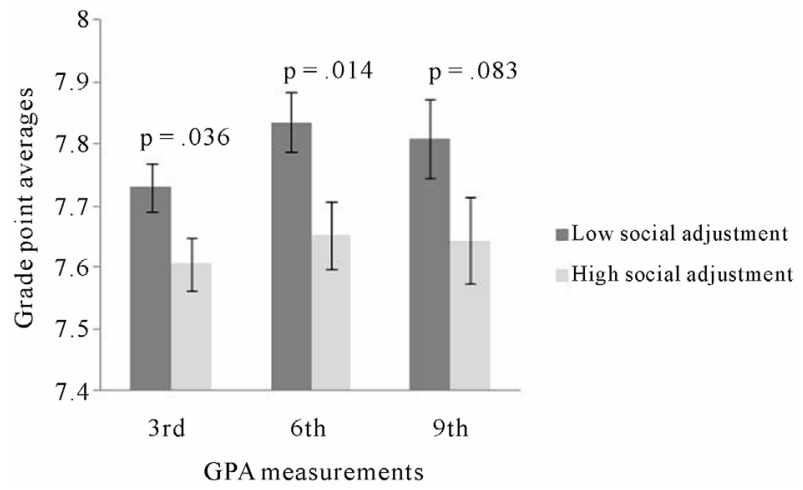

Figure 2.

The fully adjusted grade point averages (GPAs) over the three measurements $\left(3^{r d}, 6^{\text {th }}\right.$, and $9^{\text {th }}$ grade) among boys with low and high aggression, hyperactivity and social adjustment, respectively.

predictor of later academic success than standardized tests (e.g. baccalaureate) (Rantanen, 2004).

Third limitation associates with the non-standardized measurement of disruptive behaviour. By the start of our study in 1980 , there were not many appropriate measurements of disruptive behaviour. Although it is possible that the full domain of disruptive behaviour has not been reached, the reliability and validity of the measurement has been shown to be reasonable in several previous studies (Katainen \& Raikkonen, 1999; Räikkönen et al., 2000).

Finally, we may not exclude the possibility that mothers' report of child's behaviour may be reflected by the quality of mother-child relationship and even by mother's own personality. It has for example been shown that maternal depression has an impact on their perceptions of child's behaviour (Pesonen et al., 2003; Whiffen, 1990).

In the present study we showed a gender specific association 
of the different components of disruptive behaviour with school performance. Disruptive behaviour started to predict school performance before school age, and predicted school performance throughout the compulsory education, even after controlling for maternal education. Our results emphasize the importance of early identifying of children with disruptive behaviour.

\section{Acknowledgements}

This study was supported by the Academy of Finland (grant 124399 for L.K.-J. and grant 123621 for L.P.-R.), The Research Funds of the University of Helsinki (L.P.-R.), Alfred Kordelin's Foundation (S.A.), Finnish Cultural Foundation, Päijät-Häme Regional fund (S.A.), Oskar Öflund's Foundation (S.A.), Emil Aaltonen Foundation (M.H.) and Ella and Georg Ehrnrooth Foundation (M.H).

\section{References}

Abdi, H. (2007). Bonferroni and sidak corrections for multiple comparisons. In N. J. Salkind (Ed.), Encyclopedia of measurement and statistics (pp. 103-107). Thousand Oaks (CA): Sage.

Alatupa, S., Pulkki-Råback, L., Hintsanen, M., Ravaja, N., Raitakari, O. T., Telama, R., et al. (2010). School performance as a predictor of adulthood obesity: A 21-year follow-up study. European Journal of Epidemiology, 25, 267-74. doi:10.1007/s10654-010-9428-6

American Psychiatric Association. (2007). Attention-deficit and disruptive behaviour disorders. DSM-IV-TR. Fourth ed. Arlington: VA: American Psychiatric Association, 85-102.

Archer, J. (2004). Sex differences in aggression in real-world settings: A meta-analytic review. Review of General Psychology, 8, 291-322. doi:10.1037/1089-2680.8.4.291

Asendorpf, J. B., Denissen, J. J., \& van Aken, M. A. (2008). Inhibited and aggressive preschool children at 23 years of age: Personality and social transitions into adulthood. Developmental Psychology, 44, 997-1011. doi:10.1037/0012-1649.44.4.997

Berger, M., Yule, W., \& Rutter, M. (1975). Attainment and adjustment in two geographical areas: II-the prevalence of specific reading retardation. The British Journal of Psychiatry, 126, 510-519. doi:10.1192/bjp.126.6.510

Boylan, K., Vaillancourt, T., Boyle, M., \& Szatmari, P. (2007). Comorbidity of internalizing disorders in children with oppositional defiant disorder. European Child \& Adolescent Psychiatry, 16, 484-494. doi:10.1007/s00787-007-0624-1

Breslau, J., Miller, E., Breslau, N., Bohnert, K., Lucia, V., \& Schweitzer, J. (2009). The impact of early behavior disturbances on academic achievement in high school. Pediatrics, 123, 1472-1476. doi:10.1542/peds.2008-1406

Caspi, A., Elder, G. H., \& Bem, D. J. (1987). Moving against the world Life-course patterns of explosive children. Developmental Psychology, 23, 308-313. doi:10.1037/0012-1649.23.2.308

Caspi, A., \& Henry, B. (1995). Temperamental origins of child and adolescent behavior problems: From age three to age fifteen. Child Development, 66, 55-68. doi:10.2307/1131190

Dougherty, L. R. (2006). Children's emotionality and social status: A meta-analytic review. Social Development, 15, 394-417. doi:10.1111/j.1467-9507.2006.00348.x

Else-Quest, N. M., Hyde, J. S., Goldsmith, H. H., \& Hulle, C. A. V. (2006). Gender differences in temperament: A meta-analysis. Psychological Bulletin, 132, 33-72. doi:10.1037/0033-2909.132.1.33

Fagot, B. I., \& Hagan, R. (1985). Aggression in toddlers: Responses to the assertive acts of boys and girls. Sex Roles, 12, 341-351. doi:10.1007/BF00287600

Fergusson, D. M., Horwood, L. J., \& Lynskey, M. T. (1993). The effects of conduct disorder and attention deficit in middle childhood on offending and scholastic ability at the age 13. Journal of Child Psychology and Psychiatry, 34, 899-916. doi:10.1111/j.1469-7610.1993.tb01097.x

Fergusson, D. M., \& John Horwood, J. (1995). Early disruptive behav- ior, IQ, and later school achievement and delinquent behavior. Journal of Abnormal Child Psychology, 23, 183-99.

doi:10.1007/BF01447088

Frick, P. J., Kamphaus, R. W., Lahey, B. B., Loeber, R., Christ, M. A., Hart, E. L., et al. (1991). Academic underachievement and the disruptive behaviour disorders. Journal of Consulting \& Clinical Psychology, 59, 289-94. doi:10.1037/0022-006X.59.2.289

Spira, E. G., \& Fischel, J. E. (2005). The impact of preschool inattention, hyperactivity, and impulsivity on social and academic development: A review. Journal of Child Psychology and Psychiatry, 46, 755-773. doi:10.1111/j.1469-7610.2005.01466.x

Hawkins, J. D., \& Lishner, D. M. (1987). Schooling and delinquency. In E. H. Johnson (Ed.), (pp. 179-221). New York: Guilford Press.

Heiervang, E., Stevenson, J., Lund, A., \& Hugdahl, K. (2001). Behaviour problems in children with dyslexia. Nordic Journal of Psychiatry, 55(4), 251-256. doi:10.1080/080394801681019101

Hinshaw, S. (1992a). Academic underachievement, attention deficits, and aggression: Comorbidity and implications for intervention. Journal of Consulting and Clinical Psychology, 60, 893-903. doi:10.1037/0022-006X.60.6.893

Hinshaw, S. (1992b). Externalizing behavior problems and academic underachievement in childhood and adolescence: Causal relationships and underlying mechanisms. Psychological Bulletin, 111, 108126. doi:10.1037/0033-2909.111.1.127

Johnson, C., Ironsmith, M., Snow, C. W., \& Poteat, G. M. (2000). Peer acceptance and social adjustment in preschool and kindergarten. Early Childhood Education Journal, 27, 207-212 doi:10.1023/B:ECEJ.0000003356.30481.7a

Johnson, W., McGue, M., \& Iacono, W. G. (2005). Disruptive behavior and school grades: Genetic and environmental relations in 11-year-olds. Journal of Educational Psychology, 97, 391-405. doi:10.1037/0022-0663.97.3.391

Katainen, S., \& Räikkönen, K. (1999). Maternal child-rearing attitudes and role satisfaction and children's temperament as antecedents of adolescents' depressive tendencies: Follow-up study of6- to 15years-olds. Journal of Youth \& Adolescence, 28, 139-16. doi:10.1023/A:1021645213549

Keltikangas-Järvinen, L., Pulkki-Råback, L., Puttonen, S., Viikari, J., \& Raitakari, O. T. (2006). Childhood hyperactivity as a predictor of carotid artery intima media thickness over a period of 21 years: The cardiovascular risk in young finns study. Psychosomatic Medicine, 68, 509-516.

Kokko, K., Bergman, L. R., \& Pulkkinen, L. (2003). Child personality characteristics and selection into long-term unemployment in finnish and swedish longitudinal samples. International Journal of Behavioral Development, 27, 134-144. doi:10.1080/01650250244000137

Kokko, K., \& Pulkkinen, L. (2000). Aggression in childhood and long-term unemployment in adulthood: A cycle of maladaptation and some protective factors. Prevention \& Treatment, 3, 1-17. doi:10.1037/1522-3736.3.1.332a

Kokko, K., Pulkkinen, L., \& Puustinen, M. (2000). Selection into long-term unemployment and its psychological consequences. International Journal of Behavioral Development, 24, 310-320. doi:10.1080/01650250050118295

Kuncel, N. R., Credé, M., \& Thomas, L. L. (2005). The validity of self-reported grade point averages, class ranks, and test scores: A meta-analysis and review of the literature. Review of Educational Research, 75, 63-82. doi:10.3102/00346543075001063

Kuusela, J. (2003). Lukioiden tuloksiin vaikuttavista tekijöistä (from the factors affecting the results in senior high schools) (Copy No. 13). Helsinki: Edita Prima.

Loe, I. M., \& Feldman, H. M. (2007). Academic and educational outcomes of children with ADHD. Journal of Pediatric Psychology, 32, 643-654. doi:10.1093/jpepsy/js1054

Loeber, R., Burke, J., D., Lahey, B. B., Winters, A. B. A., \& Zera, M. B. A. (2000). Oppositional defiant and conduct disorder: A review of the past 10 years, part I. Journal of the American Academy of Child \& Adolescent Psychiatry., 39, 1468-1484. doi:10.1097/00004583-200012000-00007

Lynch, J. W., Kaplan, G. A., \& Salonen, J. T. (1997). Why do poor people behave poorly? Variation in adult health behaviours and psychosocial characteristics by stages of the socioeconomic lifecourse. Social Science \& Medicine, 44, 809-819. 
doi:10.1016/S0277-9536(96)00191-8

Maccoby, E. E. (1990). Gender and relationships: A developmental account. American Psychologist, 45, 513-520. doi:10.1037/0003-066X.45.4.513

Maughan, B., Pickles, A., Hagell, A., Rutter, M., \& Yule, W. (1996). Reading problems and antisocial behaviour: Developmental trends in comorbidity. Journal of Child Psychology \& Psychiatry \& Allied Disciplines, 37, 405-418. doi:10.1111/j.1469-7610.1996.tb01421.x

McGee, R., Prior, M., Williams, S., Smart, D., \& Sanson, A. (2002). The long-term significance of teacher-rated hyperactivity and reading ability in childhood: Findings from two longitudinal studies. Journal of Child Psychology \& Psychiatry \& Allied Disciplines, 43, 10041017. doi:10.1111/1469-7610.00228

McIntyre, M. H., \& Edwards, C. P. (2009). The early development of gender differences. Annual Review of Anthropology, 38, 83-97. doi:10.1146/annurev-anthro-091908-164338

Newcomb, A. F., Bukowski, W. M., \& Pattee, L. (1993). Children's peer relations: A meta-analytic review of popular, rejected, neglected, controversial, and average sociometric status. Psychological Bulletin, 113, 99-128.

Pesonen, A., Räikkönen, K., Keskivaara, P., \& Keltikangas-Järvinen, L. (2003). Difficult temperament in childhood and adulthood: Continuity from maternal perceptions to self-ratings over 17 years. Personality \& Individual Differences, 34, 19-31. doi:10.1016/S0191-8869(02)00021-1

Pulkki-Råback, L., Elovainio, M., Kivimäki, M., Raitakari, O. T., \& Keltikangas-Järvinen, L. (2005). Temperament in childhood predicts body mass in adulthood: The cardiovascular risk in young Finns study. Health Psychology, 24, 307-15.

Räikkönen, K., Katainen, S., Keskivaara, P., \& Keltikangas-Järvinen, L. (2000). Temperament, mothering, and hostile attitudes: A 12-year longitudinal study. Personality and Social Psychology Bulletin, 26, 3-12.

Raitakari, O. T., Juonala, M., Kähönen, M., Taittonen, L., Laitinen, T., Mäki-Torkko, N., et al. (2003). Cardiovascular risk factors in childhood and carotid artery intima-media thickness in adulthood: The cardiovascular risk in young finns study. JAMA, 290, 2277-2283. doi:10.1001/jama.290.17.2277

Rantanen, P. (2004). Valinnasta työelämään: Ammatillisen koulutuksen ja ammattikorkeakoulujen opiskelijavalinnan tarkastelua (No. 19). Helsinki: Opetusministeriö, Koulutus- ja Tiedepolitiikan Osasto.

Reinke, W. M., Herman, K. C., Petras, H., \& Ialongo, N. S. (2008). Empirically derived subtypes of child academic and behavior problems: Co-occurrence and distal outcomes. Journal of Abnormal Child Psychology, 36, 759-770. doi:10.1007/s10802-007-9208-2

Rhee, S., \& Waldman, I. (2002). Genetic and environmental influences on antisocial behaviour: A meta-analysis of twin and adoption studies. Psychological Bulletin, 128, 490-529. doi:10.1037/0033-2909.128.3.490

Richman, N., Stevenson, J., \& Graham, P. (1982). Preschool to school: A behavioural study. San Diego, CA: Academic Press.

Rucklidge, J. J. (2010). Gender differences in attention-Deficit/Hyperactivity disorder. Psychiatric Clinics of North America, 33, 357-373. doi:10.1016/j.psc.2010.01.006

Rutter, M. (1974). Emotional disorder and educational underachievement. Archives of Disease in Childhood, 49, 249-256. doi:10.1136/adc.49.4.249

Serbin, L. A., O’leary, K. D., Kent, R. N., \& Toniek, I. J. (1973). A comparison of teacher response to the preacademic and problem behavior of boys and girls. Child Development, 44, 796-804. doi: $10.2307 / 1127726$

Sirin, S. R. (2005). Socioeconomic status and academic achievement: A meta-analytic review of research. Review of Educational Research, 75, 417-53. doi: $10.3102 / 00346543075003417$

Stevenson, J., Richman, N., \& Graham, P. (1985). Behaviour problems and language abilities at three years and behavioural deviance at eight years. Journal of Child Psychology \& Psychiatry \& Allied Disciplines, 26, 215-230. doi:10.1111/j.1469-7610.1985.tb02261.x

Tilastokeskus. (2010). Rikoksista selvitetttiin 59\%. URL (last checked 17 June 2011)

http://tilastokeskus.fi/til/polrik/2009/polrik_2009_2010-04-06_tie_00 1 fi.html

Tremblay, R. E., \& Masselink, B. (1992). Early disruptive behavior, poor school achievement, delinquent behavior, and delinquent. Journal of Consulting \& Clinical Psychology, 60, 64-72. doi:10.1037/0022-006X.60.1.64

Trzesniewski, K. H., Moffitt, T. E., Caspi, A., Taylor, A., \& Maughan, B. (2006). Revisiting the association between reading achievement and antisocial behavior: New evidence of an environmental explanation from a twin study. Child Development, 77, 72-88. doi:10.1111/j.1467-8624.2006.00857.x

Vitaro, F., Larocque, D., Janosz, M., \& Tremblay, R. E. (2001). Negative social experiences and dropping out of school. Educational Psychology, 21, 401-415. doi:10.1080/01443410120090795

Vitaro, F., Brendgen, M., Larose, S., \& Trembaly, R. E. (2005). Kindergarten disruptive behaviors, protective factors, and educational achievement by early adulthood. Journal of Educational Psychology, 97, 617-629. doi:10.1037/0022-0663.97.4.617

Wells, E. (1980). Behavioral pattern of children in school. Vitality Health Statistics, No. 113

Whiffen, V. E. (1990). Maternal depressed mood and perceptions of child temperament. Journal of Genetic Psychology, 151, 329-339. doi:10.1080/00221325.1990.9914621

Willcutt, E. G., Pennington, B. F., \& DeFries, J. C. (2000). Twin study of the etiology of comorbidity between reading disability and attention-deficit/hyperactivity disorder. American Journal of Medical Genetics, 96, 293-301. doi:10.1002/1096-8628(20000612)96:3<293::AID-AJMG12>3.0.CO $\frac{\mathrm{i} 2-\mathrm{C}}{\mathrm{d}-\mathrm{i}: 10.1}$

Willcutt, E. G., \& Pennington, B. F. (2000). Psychiatric comorbidity in children and adolescents with reading disability. Journal of Child Psychology \& Psychiatry \& Allied Disciplines, 41, 1039-1048. doi:10.1111/1469-7610.00691

Williams, S., \& McGee, R. (1994). Reading attainment and juvenile delinquency. Journal of Child Psychology \& Psychiatry \& Allied Disciplines, 35, 441-459. doi:10.1111/j.1469-7610.1994.tb01733.x 